KOBALTANA: PALE FIRE's Mystery Spot

The Secret to the Treasure is the Treasure (esoteric saying)

\title{
TREASURE:
}

There is an unsolved mystery in Nabokov's Pale Fire - the hiding place of Zembla's crown jewels. A closed loop in the index goes from "Crown Jewels," which takes one to "Hiding place," which refers to "Potaynik," which in turn refers to "Taynik, Russ., secret place; see Crown Jewels." Nabokov, when asked by the critic Alfred Appel Jr. for the location of Pale Fire's crown jewels, offered an equally mystifying circumlocution: "In the ruins, sir, of some old barracks near Kobaltana (q.v.); but do not tell it to the Russians." (SO, 92) Kobaltana is indeed listed in Pale Fire's index as "a once fashionable mountain resort near the ruins of some old barracks now a cold and desolate spot of difficult access and no importance but still remembered in military families and forest castles, not in the text." This set-up makes clear that Nabokov wants us to play this game of hide-and-seek. One would expect that the reward of discovering the crown jewels would be more than a clever game; it should be a satisfying key to the novel. We shall see.

John Shade's poem is also circular, the unfinished last line suggesting a return to the first line. The circle returning on itself is an ancient symbol, used also in alchemy, of the snake eating its tail - the uroboros. Carl Jung saw the uroboros as a mandala, the ultimate symbol of wholeness, which he termed the true self. If we let Pale Fire's Jungian motifs of alchemy and archetype be our guide in the search for the crown jewels, we may find them in a surprising corner of Zembla. If Zembla is indeed the realm of Professor Botkin's unconscious, then it should make sense that "treasure" would be "buried" there. As Jung writes, regarding alchemy as psychology:

"Man at his birth is 'endowed with the perfect light of nature'...Paracelsus calls it ... 'the first and best treasure which the monarchy of nature hides within itself,' in 
this concurring with the world-wide descriptions of the One as the pearl of great price, the hidden treasure, the 'treasure hard to attain,' etc." (CW, V.8, 193)

We will go through the text and examine the different ways that hints to the crown jewels and treasure have appeared, and see if they fit Jung's description.

The Russians are trying to get their hands on Zembla's crown jewels. The Russian agents are amusingly doubled in the Index as: "Andronnikov and Niagarin, two Soviet experts in quest of a buried treasure, 130, 681, 741; see Crown Jewels.” (I, 231) and "Niagarin and Andronnikov, two Soviet "experts" still in quest of a buried treasure, 130, 681, 741; see Crown Jewels." The point to note here, aside from another loop in the maze, is that the jewels are referred to as "buried treasure." The bungling agents are also referred to in the text as "treasure hunters." $(\mathrm{C}, 186)$ "Treasure" is thus synonymous with "crown jewels."

Andronnikov and Niagarin, rapping and ripping their way through the castle's picture gallery, come upon a portrait of the former Keeper of the Treasure, decrepit Count Kernel, who was "painted with fingers resting lightly on an embossed and emblazoned box whose side facing the spectator consisted of an inset oblong made of real bronze, while upon the shaded top of the box, drawn in perspective, the artist had pictured a plate with the beautifully executed, twin-lobed, brainlike, halved kernel of a walnut." (C, 1012). The portrait, by the trompe l'oeil artist Eystein, had a real inset piece of bronze, which the duo rightly guessed hid a recessed box for the treasure. On the other side of the wall the King and his pal Odon are plotting the escape, and, hearing the Russian agents at their work, Odon says, "They are in for a surprise." They were; the hidden receptacle has only the broken shell of a walnut. Odon apparently knew this because the last Keeper of the Treasure, Baron Bland, we are told, "had succeeded in hiding those jewels before he jumped or fell from the North Tower; but they did not know he had had a helper and were wrong in thinking the jewels must be looked for in the palace which the gentle whitehaired Bland had never left except to die" (C, 186). Odon, the clever trickster must have helped remove the treasure from the palace. But what could have been in the broken nut shell but the "brainlike" kernel of the walnut. This suggests that the brain must be a hint to the treasure. 
There are other places to look for the treasure; Rippleson caves, for instance, where a motorboat awaits the King's escape. "It was decided to part, Charlie proceeding toward the remote treasure in the sea cave, and Odon remaining behind as a decoy" (C, 108). Odon meets up again with Charles at the Rippleson ${ }^{1}$ caves, but we never learn what else transpires on that particular leg of Kinbote's journey. My paper, “Kinbote's Hero's Journey," 2 traces Kinbote's escape from Zembla to New Wye as a clear parody of the Jungian mythologist Joseph Campbell's The Hero with a Thousand Faces. Caves are classic symbols for threshold entries to the underworld. They are womb/rebirth images. Sea caves, or grottoes signify the hero's "night sea journey" into the depths of the unconscious. Campbell says, "The very cave you are afraid to enter turns out to be the source of what you are looking for." Kobaltana is a "mountain resort," so if the treasure were in the sea cave, it must have been subsequently removed - presumably returned to King Charles.

Kinbote next shows up in the south of France, to visit his estranged exiled wife, Queen Disa, and have her sign some documents. When she inquires about the crown jewels, "he reveals to her their unusual hiding place," and she melts in "girlish mirth as she had not done for years and years." ( $\mathrm{C}, 163)$ So, the hiding place is somewhere cleverly unexpected and amusing enough to make melancholy, dismal Disa laugh. Less amusing, and quite touching, steadfast and lovely Disa, herself is actually described as a "treasure." In a surprisingly sincere and solemn passage Kinbote delivers a paean to his wife far more moving, and heartfelt than anything written by poet Shade to his wife Sybil; how, despite the ways he betrays her, she haunts his dreams with tender and desperate love while, "the sexual scum remained somewhere far above the sunken treasure." As I describe in my "Vanessa atalanta: Butterfly of Doom," forlorn Disa represents the anima as the neglected soul, pining for union. As Jung says:

\footnotetext{
1 "Rippleson" is likely an allusion to the eminent alchemist and poet, George Ripley (c.1415-1490)

2 Ross, Mary. Kinbote's Hero's Journey: Transcendent Path or Dead End?, (Unpublished) https://independent.academia.edu/MaryRoss22

3 1991, Reflections on the Art of Living: A Joseph Campbell Companion, Selected and edited by Diane K. Osbon, Quote Page 8 and 24, HarperCollins, New York, New York.
} 
"Our greatest treasure is that which is hidden deep within our own subconscious, it is the dark unused part of the self that is in fact light that is unconscious of itself." (Jung, V.13, 99)

“...the anima contains the secret of the precious stone..." (CW, V.13, 99)

"...man has a soul and there is a buried treasure in the field..." (Letters, Letter to Eugene Rolfe, 1960)

The "treasure" is his own soul, the world of true feeling, the boon that his anima holds for him, that his ego self ignores in favor of self-seeking aggrandizement and sterile pleasure.

The word "treasure" is used another time in relation to Disa. An entry in the Index under Charles II, says, "his letter of April 2, 1959, to a lady who left it locked up among her treasures in her villa near Nice when she went that summer to Rome, 768". The two Russian agents, Andronnikov and Niagarin, believing the crown jewels to be in her possession, break in and rifle Disa's villa, but fail to find them. This suggests that, while the soul (anima) has many treasures, the ultimate treasure is something else. Jung writes of the ultimate goal of the alchemists:

For the alchemists it was wisdom and knowledge, truth and spirit, and its source was in the inner man ... What they evidently had in mind was a ubiquitous and allpervading essence, an anima mundi and the 'greatest treasure,' the innermost secret numinosum of man. There is probably no more suitable psychological concept for this than the collective unconscious, whose nucleus and ordering 'principle' is the self (the 'monad' of the alchemists and Gnostics). (CW, V. 14, 298)

"Anima mundi" means "soul of the world," that is, the impersonal, rather than personally constellated anima.

"Treasure" is found in another, more unusual place: Joseph Lavender's licentious Villa Libitina. Lavender's sensational photographic art collection of ombrioles, combining "exquisite beauty with highly indecent subject matter - nudities blending with fig trees, oversize ardors, softly shaded hindercheeks, and also a dapple of female 
charms." (C, 152) While in the south of France, Kinbote apparently visits the villa ("The King was here" written on the outhouse wall). Gradus hopes to find him there, but the King is gone when he arrives. He asks the resident governess, Mlle Baud, to see the collection, but she "hastened to confess her total ignorance of her employer's hobbies and treasures." Nabokov chose his words with the utmost precision; having clearly created a treasure hunt with the crown jewels, it is unlikely he would employ "treasure" indifferently. Likewise with the word ombrioles, which mean "shades" or "shadows." Everything about the Villa Libitina suggests the dark unconscious: shadows, death, sexuality, and art. This is a hint that the treasure is associated with the unconscious. The allusion to the poet John Shade and exquisite beauty of the photos suggest that "treasure" and "art" are synonymous.

Looking back over the above hints at treasure, what we find are intimations to the Tri-Part man: body, heart/soul and mind/spirit. (As I describe in my paper The Tri-Part Man, Shade, Kinbote and Gradus make up the three major parts of one man - Botkin.) First the brainlike walnut, as mind; Then Disa as the anima/soul; Now, thirdly, ombrioles suggest the body's sexuality. These triads correlate with Kinbote's description of the crown jewels: "my gemmed scepter, ruby necklace, and diamond-studded crown," which he says are lying "snug... in - no matter where." The gemmed scepter is the phallus, the bodily "treasure" (referred in slang as the "family jewels"). The ruby necklace, presumably pendant, hangs over the heart; its ruby color connects it actually with Sybil, but Sybil is really just the older version of Disa, both representing the anima/soul/heart. The diamond studded crown sits upon the head-enclosed brain, denoting intellectual brilliance of $\mathrm{mind} / \mathrm{spirit}$.

Another mention of "treasure" occurs as Oswin Bretwit, Zembla's ex-consul in Paris, believing that the "precious papers" from "Baron B" that Gradus is bringing are a "valuable stamp collection" instead of worthless old letters, says, "I suppose you want some money for bringing this treasure?" (C, 138) Bretwit, in his disappointment, may be using the word as sulkily sarcasm, but he was expecting a precious and valuable treasure from Baron B. Baron B must surely be "Baron Bland" 
the Keeper of the Treasure. The fact that Baron B., "a harmless old codger" is listed in the Index, but not "gentle white-haired" Baron Bland, is unlikely an oversight, but part of the puzzle. The word "stamp" occurs one other time, in Shade's poem, suggesting something truly precious:

$[\ldots]$ on the damp

Gemmed turf a brown shoe lay! My secret stamp,

The Shade impress, the mystery inborn. $(\mathrm{P}, 53)$

Shade's secret stamp, his innermost mystery lies on the jeweled (gemmed) turf. The fact that it is in the form of a shoe is not without import. Shoes and boots are mentioned throughout Pale Fire. The name "Botkin" derives from a boot-maker. No wonder that Shade's manuscript, which Kinbote calls "my treasure" is under (or, if you will, "within") a pile of booties!

"In the course of that chaotic night I found a moment to transfer the poem from under the booties of Goldsworth's four nymphets to the austere security of my black valise, but only at daybreak did I find it safe enough to examine my treasure." (C, 225)

The treasure of the manuscript is not really Kinbote's, but Botkin's. Shade and Kinbote are both archetypal aspects of Botkin. Shade, as persona, evinces the higher side of the personality and thus has some access to inner mystery, whence the poetry originates. Kinbote, as ego feels empty and insecure and unable to produce creatively and so wants to appropriate Shade's manuscript and call it his own. The ego seeks the glory of pride of ownership. Like an insecure ego, Kinbote literally covers himself with the envied treasure to gather to himself an idealized persona. The twelve "precious variants" - precious because ones cribbed by himself 
- he places next to his heart, in his "innermost left-breast pocket" (My emphasis).

And like an insecure ego, he is in constant fear of being found out.

"I cannot recall without a shudder the lugubrious week that I spent in New Wye before leaving it, I hope, forever. I lived in constant fear that robbers would deprive me of my tender treasure." (C, 228)

Compare this to Fyodor's tender paranoia in The Gift:

"...but for some reason he got the impression that all these cold, slippery eyes, looking at him as if he were carrying an illegal treasure (which his gift was, essentially), belonged only to malicious hags and crooked hucksters." (TG, 80-81)

The manuscript itself is not the real treasure; the real treasure is the source of creativity within. As Jung states:

"We know from numerous hints that man's inner life is the 'secret place' where the aqua solvens et coagulans, the medicina catholica or panacea, the spark of the light of nature, are to be found." (CW, V.14, 254)

Why is the treasure always secret, or buried? Secrecy was at the heart of the alchemical process. It was intended to be arcane and obscure and for the very committed elite. The texts are deliberately obscure and symbolic. To be among the privileged, charged with arcane secrets of the Universe was part of the allure of the "aurum non vulgi," (uncommon gold - the divine spark). The real reason for secrecy, though was that this "philosophic gold" was immaterial and ineffable, yet experiential. It could only be hinted at obliquely until, through practice and meditation the artifex achieved the state of knowledge. In a sense, the secret of the mystery is the mystery.

Nabokov often uses the word "secret" to denote this innermost self. In his Lectures on Literature he writes:

"That human life is but a first installment of the serial soul and that one's individual secret is not lost in the process of earthly dissolution, becomes something more than an optimistic conjecture, and even more than a matter of 
religious faith, when we remember that only commonsense rules immortality out."

At his most poetical Nabokov hints at his secret spark in his poem "Fame."

"Without body I've spread, without echo I thrive, and with me all along is my secret."

(SP, Lines109-110, p. 111)

"But one day while disrupting the strata of sense

and descending deep down to my wellspring

I saw mirrored, besides my own self and the world, Something else, something else, something else." (SP, Lines 121-124, p. 113)

"Something else" is the ineffable innermost secret.

On the antithetic level, as Priscilla Meyer ${ }^{4}$ rightly argues, the jewels, diamonds, rubies, amethyst, pearls and emeralds, removed from the royal objects, can be found strewn throughout the text. One in particular seems significant: a sixty-five carat blue diamond discovered in a rock-filled seaside pail in the toy closet during Kinbote's first boyhood tunnel escapade. In his later escape, at the threshold of the tunnel Kinbote finds a mysterious talisman to take with him. We know from its later appearance in the Cedarn "cave" that he has taken a copy of his Uncle Conmal's Timon, and this is usually assumed to be it. It may be a "false scent... lovingly prepared to lead the would-be solver astray" (SM, 290). Kinbote says that when he entered the closet it was "empty now, save for the tiny volume of Timon Afinsken still lying in one corner..." $(\mathrm{C}, 103)$ How could the book "drop with a small thud" as he was removing the second shelf if it were already lying in a corner? Going back to the first tunnel adventure, it ends with Oleg saying "Ouf" as the last shelf had been replaced (C, 99). I suggest that the mysterious 
talisman, hidden there thanks to Oleg, was actually the "sixty-five-carat blue diamond" from the "situla," the toy pail - a family jewel and a happy memento of childhood (it shows up later as a pebble in his shoe [C,112]). Nabokov's reminiscences of his son's seaside pebble collecting demonstrate how precious these treasures are (SM, 308). Kinbote notes that his own father was a "conchologist," that is, he remembers his father appreciating the treasured shells and stones brought to him by the young prince. (This appears to be a motif in Pale Fire's progenitor, Ultima Thule as well with Sinusov sifting pebbles on the beach.) The blue diamond would represent "Blue Zembla"; situla is actually a term alchemists used for their alembic, so there is a transformational magic connotation to the pail, which is why I believe the diamond rather than the book is the important talisman. It points to memory, innocence, and transformation, in line with the true treasure of individuation and the Hero's Journey - a return to innocence of the true Self.

The jewels and the many motifs of sparkling, shining, glitter, opalescence etc. intimate the "divine spark" of Botkin's creative source. In fact, Kinbote begins his journey when he notices a "spark" on the key to the tunnel closet. This is perhaps the most important clue - the key to the novel is, in fact, the treasure of the divine spark. So, the treasure is within, as it is so often stated in myths, fairytales, and spiritual doctrines. On the novel's antithetic level of archetype and allegory this surely makes sense. The hermetic doctrine of Hermes Trismegistus, essential to alchemy, states "as above, so below," which suggests that there should be a corollary on the thetic plot level. On the thetic level jewels are jewels, not metaphors. I am going to suggest something I think it would not be too off-color for Nabokov to intimate: the crown jewels, that is the jewels themselves, not the objects, could have been safely, snuggly smuggled (don't laugh!) in a remote part of Kinbote's own body. Is this unexpected absurdity what caused Disa to dissolve in "girlish mirth?" 


\section{KOBALTANA :}

So, what does the name "Kobaltana" mean? How does it fit in with the "treasure within"? First, let's take apart the name. The suffix, "ana," seems to pick up on Nabokov's geographical word-play conflation of the western US, "Utana." This may have some association to the treasures that Nabokov found in the West - butterflies. Nabokov devoted his Lepidoptera studies to the "Blues." "Kobalt" is the Germanic source of the word "cobalt," known for its intense blue hue. However, unless we are looking at this as autobiography (a distinct possibility), "blue" is used most often in Pale Fire for "Blue Zembla." Perhaps this combination of part romantic imaginary US and part romantic imaginary Zembla is a good place to start. This fits in with the treasure being the secret interior of Botkin's psyche and his dual citizenship.

My dictionary ${ }^{5}$ states the word origin of cobalt as "1675-85 < German Kobalt, variant of Kobold." The dates here are relevant, because alchemists, who were particularly active in the 17th century, first discovered cobalt. Paracelsus (1493-1541), the physician and alchemist, was the first to describe cobalt ores. ${ }^{6}$ He believed their deleterious health effects were caused by mischievous mine spirits. It was not until 1735 that the Swedish chemist Georg Brandt isolated the element and named it cobalt rex, after these mine spirits, called "kobolds."

Alchemists were instrumental in glass-making - for their alembics, but also mirrors and stained glass, colored with various colors of cobalt ores. I needn't mention the import of this for Zembla, the land of reflections, mirrors and cheval glass.

\footnotetext{
${ }^{5}$ Random House Unabridged Dictionary, 2019

${ }^{6}$ The Alchemist, Issue 31, July 2017, p.2, http://www.rfcambrian.com/wp-content/uploads/2017/07/TheAlchemist-Issue-31-Cobalt.pdf)
} 
Alchemists also developed "disappearing ink" from cobalt. When the cobalt was prepared and turned into a solution it was red, after the ink dried it was transparent, but it produced a fabulous blue-green color when heated. The writing disappeared again when cooled. Need I say what this implies to Kinbote's pact with Sybil being signed in some "peculiar red ink"?

Carl Jung speculates on belief in kobolds as antecedent to alchemy:

"It seems that nature is out to prod man's consciousness towards greater expansion and greater clarity, and for this reason continually exploits his greed for metals, especially the precious ones, and makes him seek them out and investigate their properties. While so engaged it may perhaps dawn on him that not only veins of ore are to be found in the mines, but also kobolds and little metal men, and that there may be hidden in lead either a deadly demon or the dove of the Holy ghost" (CW, V.13, 119)

Nabokov mentions kobolds a number of times, to wit:

"Oh, how awful was the dry tap of the phantasmal fingernail inside the tabletop, and how little it resembled, of course, the intonation of your soul, of your life. A vulgar ghost with the tricks of a woodpecker, a disincarnate humorist, a corny cobold taking advantage of my stark-naked grief!" (Short Stories, Ultima Thule, 498)

"In the woods," said Franz, picturing to himself a dark grove of pines and oaks and that old dungeon on its wooded hill where cobolds had haunted his childhood." (KQK, 179)

"Incidentally in one compact sentence he had referred to several religions (not forgetting 'that wonderful Jewish sect whose dream of the gentle young rabbi dying on the Roman crux had spread over all Northern lands'), and had dismissed them together with ghosts and kobolds. (BS, 321)

The Wood Sprite, Nabokov's first short story, is about a wood kobold, exiled from his native Northern land. He represents the creative imagination, gone with childhood and cultural "progress."

"It was we, Rus', who were your inspiration, your unfathomable beauty, your agelong enchantment! And we are all gone, gone, driven into exile by a crazed surveyor." (TSVN, 5) 
Kobolds are what Jung called "trickster" archetypes. Tricksters can be playfully mischievous or wickedly destructive, but they are usually enchanting spell casters. I go over this in detail in my paper, "The Man in Green and the Man in Brown," wherein I highlight all the allusions to elves, sprites, fairies, nymphs etc. in Pale Fire, especially as they point to Gerald Emerald as malicious trickster archetype of Botkin's mind. Kinbote's pal Odon represents the more positive and creative cunning trickster allied with the arts and smarts. There is another very important trickster in Pale Fire - Hazel's poltergeist spirit in the barn. I am convinced that the spirit's message holds the real key to Kobaltana. I think the usual solution, "Papa do not go to old Goldsworth..." is a feint; it is horribly inelegant and facile, and it really does not make much sense that Hazel should warn her father two years in advance not to go to the neighbor's house. Nabokov, via Kinbote, urges the reader to "seek a secret design in the abracadabra." (C, 146) Unfortunately I have not been able to successfully unscramble it, but I do have a notion of a direction to investigate.

Kinbote informs us that the spirit made "scrabbling" sounds. This clearly suggests the game Scrabble, and therefore anagrams. If we begin by anagramming "Kobaltana," two variants have promise: "Nabok alta" and "Atalan bok." Priscilla Meyer associates "Nabok alta" with Nabokov's father being tossed in the air by grateful peasants, as Nabokov describes in Speak Memory, but I feel she puts too much emphasis on Nabokov's grief over his father's assassination as central to Pale Fire. Plus, the Latin gender is off. It does suggest Nabokov's ancestry in the name of the first Nabok, a $14^{\text {th }}$ century Russianized Tatar prince. This solution also suggests, then, that Pale Fire is a veiled autobiography. Another interpretation that I can 
suggest, but which also has the mis-gendered Latin, but ties in very nicely with Pale Fire's alchemy motif, is that the alchemists sometimes referred to the divine spark as homo altus. This also would suggest "Nabok alta" as autobiographical. The autobiographical aspect is interesting, suggesting the genius is in the genes and the treasure within Nabokov himself. Nabokov frequently referred to himself as, or made references to, a "conjuror," intimating the artist as magician. Conjurors have appeared as "minor" characters in Nabokov's works, such as the landlord in King, Queen, Knave. They are cameo roles for the author. The magician, of course, is a trickster. There is a magician in Pale Fire: Kinbote dubs his Negro gardener "Balthasar," the name of the black magus present at Christ's birth. In my paper, "Balthasar: Prince of Loam" I demonstrate that the gardener represents Jung's notion of the "self," the whole man, seen in alchemy and Gnosticism as the Demiurge creator. This would be Botkin, as stand in for Nabokov. He is the trickster and the self; Jung claimed that in primitive cultures the notion of God usually begins with a trickster figure.

The spirit message strongly suggests the importance of "Atalanta;" the name appears three times, barely hidden. This in turn suggests John Shade's muse and herald of his doom, the Vanessa atalanta butterfly. As I detail in my paper, "Vanessa atalanta: Butterfly of Doom," and will summarize here, the characters in Pale Fire associated with the butterfly (Sybil, Hazel, Kinbote, Gradus) each exhibit what Jung would describe as anima/animus imbalance, that is gender identity issues. The mythical story of the nymph Atalanta and the mock-myth of Swift's Vanessa (drawing from the Atalanta myth) both feature beautiful young women with 
traditional "masculine" attributes of competition and intellectualism, which makes them unmarriageable. Alchemists used the Atalanta myth, where the over-strong female energy is tamed by the male, as emblematic of the coniunctio, or "sacred marriage" of the elements for the production of the homo altus (Jung: self), represented by the philosopher's stone. The $16^{\text {in }}$ century German alchemist, Michael Meier's book, Atalanta Fugiens, a major treatise on the alchemical myth of the coniunctio, is alluded to several times in Pale Fire. (cf Ross, "Vanessa atalanta: Butterfly of Doom") I suggest that this important book, which holds so many of the secrets of Pale Fire, is intended in the anagram, "Atalan Bok."

This is not a perfect anagram. It is not conclusive, but suggestive. Nabokov has been known to employ (and I believe enjoy) near-anagrams, in much the same way that near rhymes are considered sophisticated in poetry - "The "artist Van Bock," as coy example (SO, 72). "Bok" is Swedish/Norwegian for "book," tying in with Pale Fire's pervasive Slavic motifs. Nabokov frequently hybridized allusions, so the "bok" may have connotations from other themes. "Atalan" is very suggestive of "Atalanta." The pervasive motifs of alchemy, (combinational magic, the union of opposites, sacred marriage, divine spark, transformation, transcendence, etc.) and the major theme of Pale Fire, which could be stated as "The Marriage of Art and Nature," or "The Triumph of Art and Nature," as the Atalanta myth was known. As an additional curiosity, Meier's book, Atalanta Fugiens, is subtitled "Emblemata Nova de Secretus Naturae Chymica." An anagram of "Nabokov" is "Nova Bok" (New Book). "Atalan" is also suggestive of "Atala" Chateaubriand's seminal novel which set off the Romantic era that, in a sense is also 
about art, nature, and marriage, and connects with the many Romantic writers alluded to in Pale Fire.

These clues to Kobaltana seem to be pointing, not to any locale on the thetic plot level of the book, but to its author, Botkin as stand-in for Nabokov himself. I suggest that Nabokov's description of Kobaltana, “a once fashionable mountain resort near the ruins of some old barracks now a cold and desolate spot of difficult access and no importance but still remembered in military families and forest castles, not in the text" is a droll description of himself, his very ageing body wherein the treasure, the divine spark, lies. A "barracks" is a place where many persons are lodged. From a Jungian point of view, the psyche is a place inhabited by numerous sub-personalities, the archetypes. Nabokov, over 60 at this time jocosely describes himself as "once fashionable," now in "ruins." He lampoons his retreat from fame into isolation in Switzerland as "cold and desolate spot of difficult access and no importance." Descended from a long line of military men and nobility, he indicates the importance only of family and memory: "still remembered in military families and forest castles." "[N]ot in the text" is important, because Nabokov is not in the text. Everything on the antithetic level, however, eventually points to autobiography.

Thus we find a parallel solution of the antithetic level to the thetic plot. On the thetic plot level, Kinbote hides the physical treasure within his physical body, paralleling the antithetic thematic level where the treasure of the divine spark is found within the being of Botkin/Nabokov. 


\section{WORKS CITED}

\section{BOOKS:}

Nabokov, Vladimir. Pale Fire, New York: Everyman's Library, Vintage International, 1992. $($ Poem $=\mathrm{PF}$, Commentary $=\mathrm{C}, \mathrm{F}=$ Foreword, $\mathrm{I}=$ Index $)$

--- Speak Memory, New York: Vintage International, Division of Random House, Inc., 1989. (SM)

---The Gift, New York: Vintage International, Division of Random House, Inc., 1989. (TG)

---The Stories of Vladimir Nabokov, New York: Knopf, 1995. (TSVN)

---Selected Poems, New York: Knopf, 2012. (SP)

Jung, Carl Gustav. Collected Works, Princeton: Princeton/Bollingen, 1969. (CW Vol.[xx])

--- Letters, Princeton: Princeton UP, 1973.

Ross, Mary. 'Vanessa Atalanta: Butterfly of Doom', The Nabokovian Notes 75, Spring 2018. https://thenabokovian.org/notes-commentaries/ross-sp2018 (MR 1)

--- Kinbote's Hero's Journey: Transcendent Path or Dead End?, (Unpublished) https://independent.academia.edu/MaryRoss22

Meier, Michael. Atalanta Fugiens, Emblemata Nova de Secretus Naturae Chymica, (1617), Athens/Manchester: Old Book Publishing, Ltd., 2015.

Meyer, Priscilla. Find What the Sailor Has Hidden, Wesleyan University Press, 1988. 